\title{
The Genus Antirrhinum (Snapdragon): A Flowering Plant Model for Evolution and Development
}

\author{
Andrew Hudson, ${ }^{1}$ Joanna Critchley, and Yvette Erasmus \\ University of Edinburgh, Institute of Molecular Plant Sciences, Edinburgh EH9 3JH, United Kingdom
}

\section{INTRODUCTION}

The Antirrhinum species group comprises approximately 20 morphologically diverse members that are able to form fertile hybrids. It includes the cultivated snapdragon Antirrhinum majus, which has been used as a model for biochemical and developmental genetics for more than 75 years. The research infrastructure for A. majus, together with the interfertility of the species group, allows Antirrhinum to be used to examine the genetic basis for plant diversity.

\section{RELATED INFORMATION}

For a review of the history of Antirrhinum genetics, see Schwarz-Sommer et al. (2003a). For a detailed presentation of the control of flower development in Antirrhinum, in comparison to that of other species, see Davies et al. (2006). The A. majus (snapdragon) genetic and genomic database is available at the DragonDB homepage, http://www.antirrhinum.net. The contents of this searchable database in AceDB schema include Antirrhinum sequences, mutants, maps, and publications. The Antirrhinum stock collection at The John Innes Centre can be viewed at http://www.jic.ac.uk/ STAFF/enrico-coen/Rosemary/start.htm.

Protocols for Cultivating Antirrhinum (Hudson et al. 2008a) and Propagating Antirrhinum (Hudson et al. 2008b) are also available.

\section{BACKGROUND INFORMATION}

The garden snapdragon A. majus has several centuries' history of cultivation as a flowering ornamental. It emerged as a model organism during early studies of inheritance and mutation (e.g., the volume by Darwin [1868]) because of its diploid inheritance, ease of cultivation, and variation in morphology and flower color. Laboratory lines of $A$. majus were produced from cultivars, and a substantial collection of mutants had amassed during the course of the 20th century. This collection included lines with unstable mutations in pigment genes, which produced variegated flowers (Fig. 1a). (A wild-type A. majus flower is shown in Fig. 1b.) Transposons responsible for flower variegation were identified in the 1980s at the John Innes Centre in Norwich, United Kingdom, and the MaxPlanck-Institut in Cologne, Germany, allowing genes involved in flower and leaf development and in pigmentation to be isolated by transposon tagging. A. majus subsequently provided the first insights into the regulation of many developmental processes that are conserved in flowering plants, including the specification of flower and floral organ identity, leaf and flower asymmetry, and the pollen component of gametophytic self-incompatibility. Because A. majus diverged from the more commonly used eudicot model Arabidopsis thaliana early in the history of flowering plants, it has proven to be useful in comparative developmental studies.

${ }^{1}$ Corresponding author (andrew.hudson@ed.ac.uk) 
The Antirrhinum species group also has a history of use in studies of natural variation. The close relatives of $A$. majus form a monophyletic group of approximately 20 species native to the Mediterranean region, particularly southwestern Europe and northern Africa. The species vary widely in morphology and ecology and are adapted to different-often extreme-habitats. However, all are able to form fertile hybrids with one another and with A. majus, allowing the identification of genes that underlie their differences (see, e.g., Langlade et al. 2005). Population genetic studies that have been applied to Antirrhinum species show different population sizes, geographic distributions, and breeding systems, from self-fertility to obligate out-crossing (see, e.g., Jiménez et al. 2002; MateuAndres and de Paco 2006).

\section{SOURCES AND HUSBANDRY}

Seeds from a large collection of $A$. majus mutants, their wild-type progenitors, and a limited number of other Antirrhinum species can be obtained from the Leibniz Institute of Plant Genetics and Crop Plant Research (IPK) in Gatersleben, Germany (http://gbis.ipk-gatersleben.de). Protocols for Antirrhinum husbandry can be found in most gardening books, and the necessary materials are readily available. Although tolerant of both frost and high temperatures, Antirrhinum species grow best at daytime temperatures of $17^{\circ} \mathrm{C}-25^{\circ} \mathrm{C}$. In temperate regions, they are usually treated as half-hardy annuals and are transferred from a glasshouse to the open in the spring or grown entirely in a glasshouse. All species grow well from seeds, most flowering within 3-4 mo of sowing, and are readily propagated clonally from cuttings. Detailed methods for Antirrhinum culture and propagation are provided in Cultivating Antirrhinum (Hudson et al. 2008a) and Propagating Antirrhinum (Hudson et al. 2008b).

\section{RELATIVES OF $A$. MAJUS}

Antirhinum is a member of the asterid clade of flowering plants. The more commonly used model species Arabidopsis is a member of the second major clade of broad-leaved plants - the rosids-from which asterids diverged an estimated 120 million yr ago. Within the asterids, Antirrhinum belongs to the order Lamiales, a close relative of the order Solanales, which includes other model species such as petunia and tomato. Antirrhinum was recently placed in the family Plantaginaceae (synonymous with Veronicaceae) following a revision of the classical family Scrophulariaceae based on DNA sequence variation (Olmstead et al. 2001).

Other aspects of Antirrhinum taxonomy remain controversial. The generic epithet "Antirrhinum" is now usually reserved for the monophyletic group of Old World perennials with a diploid chromosome number of 16. However, it is still applied to a broader monophyletic group that includes species with different chromosome numbers, such as the New World Sairocarpus and the annual Misopates, with which Antirrhinum species are unable to form fertile hybrids (see, e.g., Oyama and Baum 2004). Within Antirrhinum sensu stricto, a variable number of different species have been proposed, and relationships between taxa are currently unresolved. These taxonomic problems largely reflect the young age of the genus ( $<5$ million yr) (Gübitz et al. 2003) and the effects of hybridization (see, e.g., Whibley et al. 2006); thus, attempts to reconstruct phylogenies based on nuclear or chloroplast DNA sequence variation have so far been unsuccessful (see, e.g., Jiménez et al. 2005). In the absence of a taxonomic revision based on a resolved phylogeny, the descriptions of approximately 20 species and their likely hybrids in Flora Europaea (Webb 1972) provide a realistic working guide.

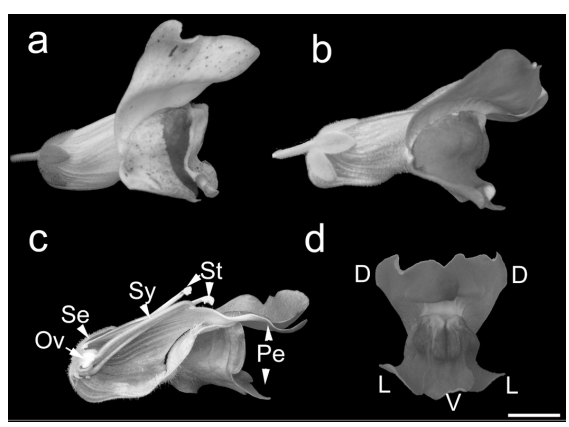

FIGURE 1. Antirrhinum majus. (a) The variegated flower caused by a transposon-induced mutation in a gene required for synthesis of anthocyanin pigments. Excision of the transposon can give rise to clones of wild-type cells able to produce magenta anthocyanins. (b) Wild-type $A$. majus flower. (c) Section of an A. majus flower, showing the four types of organs. (Ov) ovary; (Se) sepal; (Sy) style; (St) stamen; (Pe) petal. (d) Dorsoventral asymmetry of the Antirrhinum corolla. (D) Dorsal, (L) lateral, and (V) ventral petals, respectively. Bar, $10 \mathrm{~mm}$. 
The genus has traditionally been divided into three subsections or morphological groups (as in the volume by Rothmaler [1956]) that have received support from studies of isozyme and DNA variation. The subsection Antirrhinum includes the close relatives of $A$. majus and consists of species with similar upright growth, large organs, and pink or yellow flowers (Fig. 2a). These tend to be geographically widespread and grow in a variety of habitats. A. majus was probably domesticated in northeastern Spain or southwestern France from Antirrhinum pseudomajus (also known as Antirrhinum majus subspecies pseudomajus), from which it differs by having more darkly pigmented flowers, although traits such as flower color variation might have been introduced by introgression from other species. Members of subsection Kickxiella, in contrast, are usually restricted to rock faces and walls. They are also smaller, typically prostrate in habit, and have small white or pale pink flowers (Fig. 2b). They are geographically more restricted, and many are endemic to particular mountain regions. The two members of subsection Streptosepalum are pale- or yellow-flowered, of upright habit, and grow in hedges and rocky outcrops in northern Spain and Portugal (Fig. 2c). Distribution maps for all Antirrhinum species were produced by Rothmaler (1956) and can also be found in the volume by Stubbe (1966).

\section{USES OF THE A. MAJUS MODEL SYSTEM}

\section{Biochemistry}

Two aspects of Antirrhinum biochemistry relevant to their attraction of pollinating bees have been studied in detail. First, genes encoding the enzymes involved in the production of floral scentsphenylpropanoids and isoprenoids-have been identified from A. majus and used to study the regulation of scent production and the effects of variation in scent composition on pollinator attraction (see, e.g., Wright et al. 2005). Second, the basis for flower color variation in Antirrhinum has a long history of study, including the pioneering biochemical genetics of Muriel Wheldale in the early 20th century. Structural genes encoding most enzymes involved in the biosynthesis of magenta anthocyanins and the structurally related yellow aurones have been identified and isolated through a combination of genetics and biochemistry. Several regulatory genes encoding MYB or basic helix-loop-helix (bHLH) transcription factors are known to affect the intensity or pattern of pigmentation (Schwinn et al. 2006). In parallel, many of the genes underlying natural variation in Antirrhinum flower pigmentation were mapped or shown to be allelic to loci identified from mutations in A. majus. Three of the loci involved in natural variation have been isolated: Two encode the MYB transcription factors ROSEA and VENOSA, and the third is the structural gene INCOLORATA. TwO additional genes - SULFUREA (SULF), which controls aurone pigmentation, and ELUTA (EL), which is

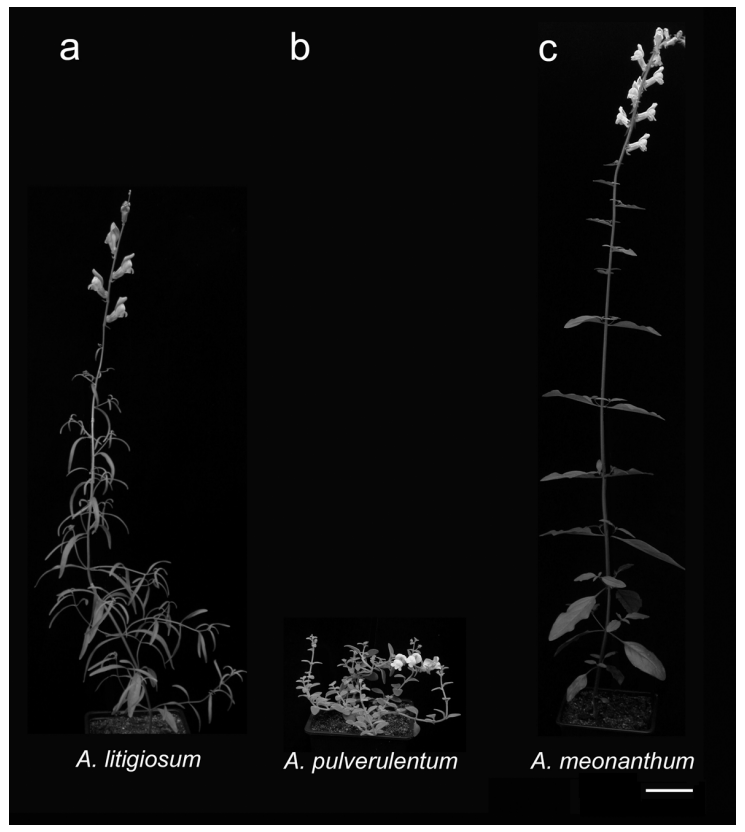

FIGURE 2. Representatives of the three traditional subsections of the genus Antirrhinum. (a) Antirrhinum litigiosum (also known as Antirrhinum majus subspecies litigiosum), a member of subsection Antirrhinum; (b) Antirrhinum pulverulentum, a member of subsection Kickxiella; (c) Antirrhinum meonanthum, a member of subsection Streptosepalum. Bar, $50 \mathrm{~mm}$. 
responsible for variation in the pigment pattern within the flower-have been mapped but not yet isolated. Flower color variation in Antirrhinum has been shown to affect pollinator behavior, and selection at loci including SULF and EL is likely to maintain the distinction between yellow-flowered Antirrhinum striatum and magenta-flowered A. pseudomajus in the face of hybridization (Whibley et al. 2006).

\section{Development}

The use of $A$. majus in parallel with other species, notably Arabidopsis, has led to an understanding of how the identity of flowers and floral organs is specified (for a recent review, see Davies et al. 2006). These processes are broadly conserved between the asterid Antirrhinum and the rosid Arabidopsis, which have similar inflorescence and floral structures (see Fig. 1c,d for the structure of the Antirrhinum flower). Both species, for example, contributed to the "ABC" model of floral organ specification, in which the combination of genes expressed in each of the whorls determines the identity of the floral organs (A genes specify sepals, A + B genes specify petals, B + C genes specify stamens, and $C$ genes specify the carpel). However, the comparative use of $A$. majus further revealed subtle evolutionary differences in the way that the development of similar flowers can be regulated. Antirrhinum and Arabidopsis, for instance, use different genes to exclude the expression of $\mathrm{C}$ genes from the outermost parts of the developing flower-a role originally attributed to A-function genesleading to a reevaluation of the A-function genes in both species (Keck et al. 2003; Davies et al. 2006). Similarly, the ancestral $C$ function appears to have been transferred to different duplicated genes after the divergence of Antirrhinum from Arabidopsis (Causier et al. 2005). One notable aspect of the Antirrhinum flower that differs from Arabidopsis is its marked dorsoventral asymmetry (zygomorphy). Zygomorphy, considered to have coevolved with insect pollination, is apparent in the different morphologies of the dorsal, lateral, and ventral petals of Antirrhinum (Fig. 1d) and in stamen development. The dorsal and lateral petals are specified by the paralogous TCP transcription factor genes CYCLOIDEA (CYC) and DICHOTOMA (DICH), which act partly by activating dorsal expression of RADIALIS (RAD). RAD is a protein with a single MYB transcription factor repeat that is thought to compete with the two-repeat MYB protein encoded by the DIVARICATA (DIV) gene to antagonize its ventralizing effect (for review, see Almeida and Galego 2005). CYC-like genes have also been implicated in the evolution of floral asymmetry in other lineages. For example, ectopic CYC expression has been proposed to account for the evolution of the derived radially symmetrical flower of Mohavea, which is within the tribe Antirrhineae (Hileman et al. 2003). CYC-like genes are expressed asymmetrically in both rosids and asterids, including species that have radially symmetrical flowers (for review, see Cubas 2004). This indicates that ancestral, asymmetrically expressed CYC-like genes might have been recruited independently to produce zygomorphic flowers in different flowering plant lineages, a view recently supported by the effects of cyc-like mutants in the asterid legume Lotus (Feng et al. 2006).

Aided by a large collection of leaf-shape mutants, A. majus has also been useful in studies of leaf development. These studies have included the identification of genes involved in specifying leaf identity and promoting leaf growth (see, e.g., Golz et al. 2004) and in coordinating growth in the leaf blade to ensure the development of a flat organ (see, e.g., Nath et al. 2003).

\section{Ecology and Population Genetics}

Antirrhinum species have been the subject of population genetic studies, including those aimed at assessing genetic diversity in order to inform conservation strategies for rare endemic species (see, e.g., Mateu-Andres 2004). As with other taxa, genetic diversity has generally been found to be lower in smaller populations, and the distribution of genetic variants within and between populations has been correlated with their level of self-incompatibility. In addition, several genetically well-characterized aspects of Antirrhinum development and physiology are relevant to their reproductive ecology, including petal cell morphology, genetic self-incompatibility, flower color, and scent production.

Whereas cultivated A. majus and some wild species (e.g., Antirrhinum valentinum, Antirrhinum subbaeticum, and Antirrhinum siculum) are self-fertile, the majority of Antirrhinum species show gametophytic self-incompatibility that is determined by a single, complex $S$ locus. Individuals of self-incompatible species reject pollen carrying an $S$ allele that corresponds to one of their own alleles and are therefore obligate outbreeders. Through studies of relatives in the family Solanaceae, rejection of pollen was known to involve an S-encoded RNase that was expressed in the pistil (McClure et al. 1989), although the pollen-expressed component had remained elusive. Mapping and sequence 
analysis of the active $S$ locus of Antirrhinum hispanicum, followed by expression and functional studies, identified the likely pollen component to be an F-box protein involved in targeting the RNase for degradation (Lai et al. 2002).

Cells of the petal epidermis of Antirrhinum, like those of many flowering plants, have a conical shape that is dependent on activity of the MYB transcription factor encoded by MIXTA. These conical cells intensify flower color by reducing reflection, as revealed by MIXTA mutants with flat epidermal cells, and are important in attracting pollinating bees (Noda et al. 1994). In addition to having a role in the reproductive ecology of Antirrhinum, the misexpression of MIXTA or related genes can give rise to the formation of epidermal hairs (trichomes), indicating a common regulation of these two cell types and a role for other MIXTA-like genes in regulating multicellular trichome development in Antirrhinum. This latter function of MIXTA-like genes does not appear to be conserved in Arabidopsis, which has unicellular trichomes (for review, see Serna and Martin 2006).

\section{GENETICS AND GENOMICS RESOURCES}

A. majus is amenable to classical genetics. It has a relatively short generation time of $\sim 4$ mo, is diploid $(2 n=16)$, and is easily self- and cross-pollinated (see Propagating Antirrhinum [Hudson et al. 2008b]). A collection of classical mutants and corresponding wild-type lines originating from the work of Erwin Baur, Hans Stubbe, and their colleagues is maintained at the IPK. The phenotypes of most of the mutants in this collection have been described by Stubbe (1966) and cataloged by Hammer et al. (1990). Additional mutants and wild-type lines, generated at the John Innes Centre, are described at http://www.jic.ac.uk/STAFF/enrico-coen/Rosemary/start.htm.

A molecular recombination map, currently comprising more than 250 loci with an average distance between loci of $\sim 2 \mathrm{cM}$, has been produced for Antirrhinum using hybrids between $A$. majus and wild species, and the map is maintained at www.antirrhinum.net. It has been aligned with a map of classical mutants and with the eight Antirrhinum chromosomes using fluorescence in situ hybridization (FISH) (Zhang et al. 2005). Maps constructed using hybrids between different Antirrhinum species are largely collinear, suggesting an absence of extensive chromosomal rearrangements, although distorted transmission of some genomic regions in interspecies hybrids can hinder genetic mapping (Schwarz-Sommer et al. 2003b). Recombinant inbred lines (RILs) and near-isogenic lines (NILs) have been produced from hybrids between different Antirrhinum species, allowing those genes that underlie differences between species to be identified.

Native Antirrhinum transposons have provided the basis for a number of genetic resources. Most spontaneous mutations in $A$. majus have been found to carry transposons belonging to one of two families: the Tam3 family, which is similar to Ac in maize; and the CACTA family, which is homologous to $\mathrm{Spm} / \mathrm{En}$ in maize. Mutagenic retroposons and miniature inverted repeat transposable elements (MITEs) have also been found. Transposition of the CACTA and Tam3 families occurs by excision from the donor site and reintegration elsewhere in the genome and is promoted by low temperature. A number of $A$. majus lines were selected for high transposon activity based on flower variegation and have been used for forward genetic screens and for inactivating known genes to study their functions (see, e.g., Keck et al. 2003).

Transposon excision from pigment genes, which can be controlled with temperature, has been used to mark cells for fate and growth analysis (e.g., Rolland-Lagan et al. 2003), and excision from developmental genes has been used to examine cell autonomy of gene action (see, e.g., Golz et al. 2004). In many cases, it has been possible to establish stable periclinal chimeras in which layers of the shoot apical meristem comprise genetically different cells as the result of transposon excision (see, e.g., Carpenter and Coen 1995). Such chimeras can be maintained by vegetative propagation through cuttings.

Although stable transgenic Antirrhinum can be produced using Agrobacterium tumefaciens (Cui et al. 2003), transformation efficiency is low. Particle bombardment and Agrobacterium infiltration of developing petals have been used successfully to obtain transient expression of pigment genes and suppression by RNA interference (RNAi) (Schwinn et al. 2006; Shang et al. 2007).

Bacterial artificial chromosome (BAC) libraries have been produced from A. majus (Causier et al. 2005) and from an $A$. majus $\times A$. hispanicum hybrid (Lai et al. 2002). Although the genome size of $A$. majus has been estimated at $430 \mathrm{Mb}$ (Bennett and Leitch 1995), the recovery of clones from genomic libraries indicates that it might be at least twofold larger; therefore, the depth of coverage of existing BAC libraries is uncertain. Currently, only short BAC contigs have been assembled to allow positional 
cloning in specific target regions (Cartolano et al. 2007). FISH has been used to locate BAC clones on Antirrhinum chromosomes (Zhang et al. 2005; Yang et al. 2007). An expressed sequence tag (EST) collection of approximately 12,000 unigenes from $A$. majus is available for searching at www.antirrhinum.net. Other DNA libraries include CDNA clones in yeast one-hybrid and two-hybrid vectors (see, e.g., Egea-Cortines et al. 1999).

\section{TECHNICAL APPROACHES}

Antirrhinum species are amenable to molecular genetic techniques. Most protocols that have been developed for Arabidopsis, including those for nucleic acid, protein, and organelle purification and for detection of RNA and proteins in situ, can be applied directly to Antirrhinum (see Cultivating Antirrhinum [Hudson et al. 2008a] and Propagating Antirrhinum [Hudson et al. 2008b]).

\section{REFERENCES}

Almeida, J. and Galego, L. 2005. Flower symmetry and shape in Antirrhinum. Int. J. Dev. Biol. 49: 527-537.

Bennett, M.D. and Leitch, I.J. 1995. Nuclear DNA amounts in angiosperms. Ann. Bot. 76: 113-176.

Carpenter, R. and Coen, E.S. 1995. Transposon induced chimeras show that floricaula, a meristem identity gene, acts nonautonomously between cell layers. Development 121: 19-26.

Cartolano, M., Castillo, R., Efremova, N., Kuckenberg, M., Zethof, J., Gerats, T., Schwarz-Sommer, Z., and Vandenbussche, M. 2007. A conserved microRNA module exerts homeotic control over Petunia hybrida and Antirrhinum majus floral organ identity. Nat. Genet. 39: 901-905.

Causier, B., Castillo, R., Zhou, J., Ingram, R., Xue, Y., SchwarzSommer, Z., and Davies, B. 2005. Evolution in action: Following function in duplicated floral homeotic genes. Curr. Biol. 15: 15081512.

Cubas, P. 2004. Floral zygomorphy, the recurring evolution of a successful trait. Bioessays 26: 1175-1184.

Cui, M.L., Handa, T., and Ezura, H. 2003. An improved protocol for Agrobacterium-mediated transformation of Antirrhinum majus L. Mol. Genet. Genomics 270: 296-302.

Darwin, C.R. 1868. Variation of animals and plants under domestication. John Murray, London.

Davies, B., Cartolano, M., and Schwarz-Sommer, Z. 2006. Flower development: The Antirrhinum perspective. Adv. Bot. Res. 44: 279-321.

Egea-Cortines, M., Saedler, H., and Sommer, H. 1999. Ternary complex formation between the MADS-box proteins SQUAMOSA, DEFICIENS and GLOBOSA is involved in the control of floral architecture in Antirrhinum majus. EMBO J. 18: 5370-5379.

Feng, X., Zhao, Z., Tian, Z., Xu, S., Luo, Y., Cai, Z., Wang, Y., Yang, J., Wang, Z., Weng, L., et al. 2006. Control of petal shape and floral zygomorphy in Lotus japonicus. Proc. Natl. Acad. Sci. 103: 4970-4975.

Golz, J.F., Roccaro, M., Kuzoff, R., and Hudson, A. 2004. GRAMINIFOLIA promotes growth and polarity of Antirrhinum leaves. Development 131: 3661-3670.

Gübitz, T., Caldwell, A., and Hudson, A. 2003. Rapid molecular evolution of CYCLOIDEA-like genes in Antirrhinum and its relatives. Mol. Biol. Evol. 20: 1537-1544.

Hammer, K., Knüpffer, H., and Knüpffer, S. 1990. Das Gaterlebener Antirrhinum-sortiment. Kulturpflanze 38: 91-117.

Hileman, L.C., Kramer, E.M., and Baum, D.A. 2003. Differential regulation of symmetry genes and the evolution of floral morphologies. Proc. Natl. Acad. Sci. 100: 12814-12819.

Hudson, A., Critchley, J., and Erasmus, Y. 2008a. Cultivating Antirrhinum. Cold Spring Harb. Protoc. (this issue). doi: 10.1101/ pdb.prot5051.

Hudson, A., Critchley, J., and Erasmus, Y. 2008b. Propagating Antirrhinum. Cold Spring Harb. Protoc. (this issue). doi: 10.1101/ pdb.prot5052.
Jiménez, J.F., Sánchez-Gómez, P., Güemes, J., Werner, O., and Rosselló, J.A. 2002. Genetic variability in a narrow endemic snapdragon (Antirrhinum subbaeticum, Scrophulariaceae) using RAPD markers. Heredity 89: 387-393.

Jiménez, J.F., Sánchez-Gómez, P., Güemes, J., and Rosselló, J.A. 2005. Phylogeny of snapdragon species (Antirrhinum; Scrophulariaceae) using non-coding cpDNA sequences. Isr. J. Plant Sci. 53: 47-53.

Keck, E., McSteen, P., Carpenter, R., and Coen, E. 2003. Separation of genetic functions controlling organ identity in flowers. $E M B O \mathrm{~J}$. 22: 1058-1066.

Lai, Z., Ma, W., Han, B., Liang, L., Zhang, Y., Hong, G., and Xue, Y. 2002. An F-box gene linked to the self-incompatibility (S) locus of Antirrhinum is expressed specifically in pollen and tapetum. Plant Mol. Biol. 50: 29-42.

Langlade, N.B., Feng, X., Dransfield, T., Copsey, L., Hanna, A.I., Thebaud, C., Bangham, A., Hudson, A., and Coen, E. 2005. Evolution through genetically controlled allometry space. Proc. Natl. Acad. Sci. 102: 10221-10226.

Mateu-Andres, I. 2004. Low levels of allozyme variability in the threatened species Antirrhinum subbaeticum and A. pertegasii (Scrophulariaceae): Implications for conservation of the species. Ann. Bot. 94: 797-804.

Mateu-Andres, I. and de Paco, L. 2006. Genetic diversity and the reproductive system in related species of Antirrhinum. Ann. Bot. 98: 1053-1060.

McClure, B.A., Haring, V., Ebert, P.R., Anderson, M.A., Simpson, R.J., Sakijama, F., and Clarke, A.E. 1989. Style self-incompatibility gene products of Nicotiana alata are ribonucleases. Nature 342: 955957.

Nath, U, Crawford, B.C., Carpenter, R., and Coen, E. 2003. Genetic control of surface curvature. Science 299: 1404-1407.

Noda, K., Glover, B.J., Linstead, P., and Martin, C. 1994. Flower colour intensity depends on specialized cell shape controlled by a Myb-related transcription factor. Nature 369: 661-664.

Olmstead, R.G., dePamphilis, C.W., Wolfe, A.D., Young, N.D., Elisons, W.J., and Reeves, P.A. 2001. Disintegration of the Scrophulariaceae. Am. J. Bot. 88: 348-361.

Oyama, R.K. and Baum, D.A. 2004. Phylogenetic relationships of North American Antirrhinum (Veronicacae). Am. J. Bot. 91: 918-925.

Rolland-Lagan, A.G., Bangham, J.A., and Coen, E. 2003. Growth dynamics underlying petal shape and asymmetry. Nature 422: 161-163.

Rothmaler, W. 1956. Taxonomische Monographie der Gattung Antirrhinum. Academie Verlag, Berlin.

Schwarz-Sommer, Z., Davies, B., and Hudson, A. 2003a. An everlasting pioneer: The story of Antirrhinum research. Nat. Rev. Genet. 4: 657-666.

Schwarz-Sommer, Z., de Andrade, S.E., Berndtgen, R., Lonnig, W.E., Muller, A., Nindl, I., Stuber, K., Wunder, J., Saedler, H., Gübitz, T., et al. 2003b. A linkage map of an F2 hybrid population of Antirrhinum majus and A. molle. Genetics 163: 699-710. 
Schwinn, K., Venail, J., Shang, Y., Mackay, S., Alm, V., Butelli, E., Oyama, R., Bailey, P., Davies, K., and Martin, C. 2006. A small family of MYB-regulatory genes controls floral pigmentation intensity and patterning in the genus Antirrhinum. Plant Cell 18: 831-851.

Serna, L. and Martin, C. 2006. Trichomes: Different regulatory networks lead to convergent structures. Trends Plant Sci. 11: 274-280.

Shang, Y., Schwinn, K.E., Bennett, M.J., Hunter, D.A., Waugh, T.L., Pathirana, N.N., Brummell, D.A., Jameson, P.E., and Davies, K.M. 2007. Methods for transient assay of gene function in floral tissues. Plant Methods 3: 1 doi: 10.1186/1746-4811-3-1.

Stubbe, H. 1966. Genetik und Zytologie von Antirrhinum L. sect. Antirrhinum. Gustav Fischer, Jena, Germany.

Webb, D.A. 1972. Antirrhinum L. In Flora Europaea (eds. T.G. Tutin et al.), pp. 221-224. Cambridge University Press, New York.
Whibley, A.C., Langlade, N.B., Andalo, C., Hanna, A.I., Bangham, A., Thebaud, C., and Coen, E. 2006. Evolutionary paths underlying flower color variation in Antirrhinum. Science 313: 963-966.

Wright, G.A., Lutmerding, A., Dudareva, N., and Smith, B.H. 2005. Intensity and the ratios of compounds in the scent of snapdragon flowers affect scent discrimination by honeybees (Apis mellifera). J. Comp. Physiol. A: Neuroethol. Sens. Neural Behav. Physiol. 191: 105-114.

Yang, Q., Zhang, D., Li, Q., Cheng, Z., and Xue, Y. 2007. Heterochromatic and genetic features are consistent with recombination suppression of the self-incompatibility locus in Antirrhinum. Plant J. 51: 14-151.

Zhang, D., Yang, Q., Bao, W., Zhang, Y., Han, B., Xue, Y., and Cheng, Z. 2005. Molecular cytogenetic characterization of the Antirrhinum majus genome. Genetics 169: 325-335. 


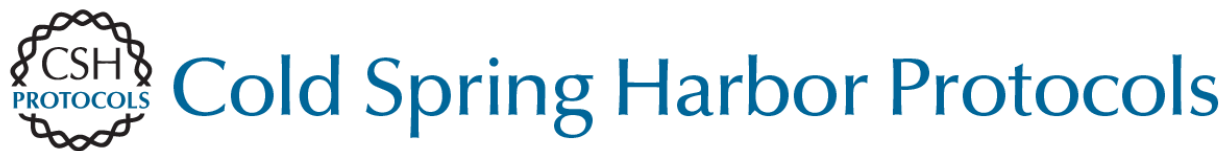

\section{The Genus Antirrhinum (Snapdragon): A Flowering Plant Model for Evolution and Development}

Andrew Hudson, Joanna Critchley and Yvette Erasmus

Cold Spring Harb Protoc; doi: 10.1101/pdb.emo100

\begin{tabular}{|c|c|}
\hline $\begin{array}{c}\text { Email Alerting } \\
\text { Service }\end{array}$ & Receive free email alerts when new articles cite this article - click here. \\
\hline $\begin{array}{l}\text { Subject } \\
\text { Categories }\end{array}$ & $\begin{array}{l}\text { Browse articles on similar topics from Cold Spring Harbor Protocols. } \\
\text { Developmental Biology (728 articles) } \\
\text { Emerging Model Organisms (321 articles) } \\
\text { Laboratory Organisms, general (923 articles) } \\
\text { Plant (105 articles) } \\
\text { Plant Biology, general (118 articles) }\end{array}$ \\
\hline
\end{tabular}

